\title{
Evaluation of Effect of Different Nitrogen Sources on Major Insect Pests Infesting Okra, Abelmoschus esculentus (L.) Moench. under Semi Arid Region of Rajasthan, India
}

\author{
S.M. Jat ${ }^{1 *}$, A.S. Baloda ${ }^{1}$, Purushotam Sharma ${ }^{1}$ and Sharwan Lal Jat ${ }^{2}$ \\ ${ }^{1}$ Department of Entomology, Rajasthan Agricultural Research Institute, \\ Durgapura, Jaipur, Rajasthan, India \\ ${ }^{2}$ SKNAU, Jobner \\ *Corresponding author
}

\section{A B S T R A C T}

\begin{tabular}{|l|}
\hline K e y w or d s \\
Okra, Insect pests, \\
Nitrogen levels, \\
Vermicompost and \\
farm yard manure
\end{tabular}

Investigations on evaluation of effect of different nitrogen sources on major insect pests infesting okra was carried out at the Department of Entomology, Rajasthan Agricultural Research Institute, Durgapura, Jaipur during kharif 2016 and 2017. The major insect pests infesting okra observed during two consecutive seasons were leaf hopper, A. biguttula biguttula; whitefly, B. tabaci and okra shoot and fruit borer and E. vittella. Different sources of nitrogen were applied as different treatments to the okra crop. The fertilizers applied were urea, vermicompost and farm yard manure and their different combinations. Maximum nitrogen content in leaf of okra was observed in treatment where, 75 percent nitrogen was applied through urea and 25 per cent was applied through vermicompost. Maximum population of leaf hopper and whitefly was observed in treatment where, all the nitrogen was applied through urea $(6.94 \& 8.37$ per plant) and minimum population was recorded from treatment where, all the nitrogen was applied through vermicompost (2.27 and 2.34 per plant). Maximum fruit infestation was recorded in treatment, where all the nitrogen was applied through urea i.e. $14.39 \%$ (on number basis) and $21.55 \%$ (on weight basis).

\section{Introduction}

India is the second largest producer of vegetables in the world (surpassed only by China) accounting for about 10 per cent of the world production. Okra, Abelmoschus esculentus (L.) Moench commonly known as bhindi or lady's finger (family: Malvaceae) is a popular fruit vegetable crop. In the plains of northern India, it is grown in summer as well as during the rainy season; whereas, in central and south India, the crop can be grown throughout the year. It is cultivated in 528.4 thousand hectares with a total production of 6146.0 thousand metric tonnes with productivity of 11.6 tonnes per hectare in India (Anonymous, 2016-17).

Okra fruit is nutritionally very rich with a caloric value of 35 . The fruits of okra contain carbohydrate $(6.4 \%)$, protein $(1.9 \%)$, fat $(0.2 \%)$, fiber $(1.2 \%)$, minerals $(0.7 \%)$ and 
moisture (89.6\%) (Anonymous, 2016). One of the important limiting factors in the cultivation of okra is insect pests. As high as 72 species of insects have been recorded on okra (Srinivas Rao and Rajendran, 2003), of which, the sucking pests comprising of Aphids (Aphis gossypii Glover), leafhopper (Amrasca biguttula biguttula Ishida), whitefly (Bemisia tabaci Gennadius) and mite (Tetranychus cinnabarinus Boisduval) causes significant damage to the crop, while at later stage fruit borers like Earias spp and Helicoverpa armigera (Hb.) cause considerable losses to the crop to the tune of 91.6 per cent (Pareek and Bhargava, 2003).

Chemical control of insect pests is generally practiced for higher gains but due to shorter interval in periodical harvest, use of chemicals alone is not advisable. Under such situation, it becomes pertinent to look for alternatives which are effective and eco friendly.

Use of organic amendments applied to soil not only enhance the nutrient status but also reduces the pest incidence, Earlier, Surekha and Rao (2001) explored the utility of organic manures for managing the pests of okra. Thus, keeping these thematic areas in view, the present investigation' evaluation of effect of different nitrogen sources on major insect pests infesting okra, Abelmoschus esculentus (L.) Moench under Semi Arid region of Rajasthan' was undertaken.

\section{Materials and Methods}

To evaluate the effect of different sources of nitrogen on incidence of major insect pest of okra, the crop was sown in experimental field at normal sowing time in twenty nine plots of $3.0 \times 2.25 \mathrm{~m}$ size, nine treatment each replicated thrice, with keeping the row to row and plant to plant distance of 45 and $30 \mathrm{~cm}$, respectively during both the year of study.

\section{Observation methodology}

\section{Sucking pests}

To record the incidence of various sucking pests, five plants were randomly selected from net plot area of each plot and tagged. Observations on population of sucking pests particularly jassid were recorded by counting the number of nymphs and adults, while only adults in case of whitefly from three leaves (top, middle and bottom) of selected plants. The observations were recorded at weekly interval starting from the germination of the crop. The data thus obtained was subjected to statistical analysis.

\section{Shoot and fruit borer (E. vittella)}

Observations on shoot infestation due to $E$. vittella was recorded on five randomly selected plants in each net plot area. The harvested fruits of each plot were carefully observed after each picking to ascertain fruit infestation and percentage of fruit infested was worked out. The data on per cent fruit damage was statistically analyzed after suitable transformation.

\section{Treatments detail}

\begin{tabular}{|l|l|}
\hline Treatment & Particular \\
\hline $\mathrm{T}_{1}$ & $100 \%$ Nitrogen through Urea \\
\hline $\mathrm{T}_{2}$ & $100 \%$ Nitrogen through FYM \\
\hline $\mathrm{T}_{3}$ & $\begin{array}{l}100 \% \text { Nitrogen though } \\
\text { Vermicompost }\end{array}$ \\
\hline $\mathrm{T}_{4}$ & $\begin{array}{l}75 \% \text { Nitrogen through Urea }+25 \% \\
\text { Nitrogen through FYM }\end{array}$ \\
\hline $\mathrm{T}_{5}$ & $\begin{array}{l}75 \% \text { Nitrogen through Urea }+25 \% \\
\text { Nitrogen though Vermicompost }\end{array}$ \\
\hline $\mathrm{T}_{6}$ & $\begin{array}{l}50 \% \text { Nitrogen through Urea }+50 \% \\
\text { Nitrogen though FYM }\end{array}$ \\
\hline $\mathrm{T}_{7}$ & $\begin{array}{l}50 \% \text { Nitrogen through Urea }+50 \% \\
\text { Nitrogen though Vermicompost }\end{array}$ \\
\hline $\mathrm{T}_{8}$ & $\begin{array}{l}25 \% \text { Nitrogen through Urea }+75 \% \\
\text { Nitrogen though FYM }\end{array}$ \\
\hline $\mathrm{T}_{9}$ & $\begin{array}{l}25 \% \text { Nitrogen through Urea }+75 \% \\
\text { Nitrogen though Vermicompost }\end{array}$ \\
\hline
\end{tabular}




\section{Estimation of nitrogen content of leaf}

Nitrogen content of leaves and fruits in different treatments was evaluated at the time of first appearance of pests. For estimation of nitrogen content in leaves and fruit samples were collected from each treatment. These sampled leaves were first dried in sun and then finally in an electric oven at $60^{\circ} \mathrm{C}$ and then ground in a mixer to make fine powder.

The nitrogen content was estimated by Kjeldahl's method as described by Jackson (1973). In this method, powdered sample of 1 g digested with concentrated $\mathrm{H}_{2} \mathrm{SO}_{4}$ in the presence of digestion mixture $\left(\mathrm{K}_{2} \mathrm{SO}_{4}\right.$ : $\mathrm{CuSO}_{4} \cdot 5 \mathrm{H}_{2} \mathrm{O}$ : $\mathrm{Se}$ in the proportion of 100 : 20:1) and distilled under alkaline medium. The liberated $\mathrm{NH}_{3}$ was trapped in 4 percent Boric acid and containing mixed indicator and titrated against standard $\mathrm{H}_{2} \mathrm{SO}_{4}$.

\section{Results and Discussion}

\section{Per cent nitrogen content in leaves of okra}

During both the year of study the nitrogen content were applied through different sources as treatments in okra crop.

The maximum nitrogen content ( 2.22 percent) in leaves of okra was recorded in treatment where $75 \%$ nitrogen was applied through urea and remaining $25 \%$ was applied through vermicompost followed by 2.14 percent in treatment where all the nitrogen was applied through urea.

The minimum nitrogen content in leaves (1.83 percent) was recorded in treatment where all the nitrogen was applied through farm yard manure followed by treatment (1.95 percent) where all the nitrogen was applied through vermicompost. All the treatments had nonsignificant difference among them.

\section{Effect of different sources of nitrogen of} incidence of sucking pests of okra

The pooled data of both the year revealed that the significantly lower population of jassid (2.27 nymphs/ 3 leaves/ plant) was recorded in the treatment where 100 per cent of the recommended dose of nitrogen was applied through Vermicompost. Similarly maximum population (6.94 nymphs/ 3 leaves/ plant) was recorded in the treatment where only chemical fertilizer i.e. urea, was applied. The pooled data of both the year revealed that, significantly lower population of whitefly (2.34 whitefly/ 3 leaves/ plant) was recorded in the treatment where the total recommended dose of nitrogen was applied through vermicompost. Similarly maximum population (8.37 whitefly/ 3 leaves/ plant) was recorded in the treatment where only chemical fertilizer i.e. urea was applied to meet the nutritional requirements of the crop. Thus, the maximum nitrogen required for the crop growth given through the organic manures i.e. vermicompost and farm yard manure recorded the lower pest population as compared to the combination with chemical fertilizers (Fig. 1, Table 1 and 2).

\section{Effect of different sources of nitrogen on} incidence of shoot and fruit borer, Earias vittella (Fabricius)

The pooled data of both the year of study on fruit infestation due to fruit borer in okra on number basis revealed that significantly the lower fruit infestation $(3.18 \%)$ due to fruit borer, Earias spp. was recorded in the treatment where total nitrogen requirement was supplied through vermicompost. Similarly, the maximum infestation 14.39 per cent was recorded where only the chemical fertilizers i.e. urea was applied. However, it was at par with the treatment where maximum dose of nitrogen $(75 \%)$ was applied through urea and remaining 25 per cent was applied 
through farm yard manure $(12.96 \%$ infestation) (Fig. 2).

The pooled data of both the year of study on fruit infestation due to fruit borer in okra on weight basis revealed that significantly the lower fruit infestation $(8.65 \%)$ due to fruit borer, Earias spp. was recorded in the treatment where total nitrogen requirement was supplied through vermicompost. Similarly, the maximum infestation of 21.55 per cent was recorded where only the chemical fertilizer i.e. urea was applied. Rest of the treatment combinations showed moderate effects with the infestation of 12.30 to 14.98 per cent (Table 3 and 4).

Table.1 Effect of different source of nitrogen on population of jassid, Amrasca biguttula biguttula (Ishida) infesting okra

\begin{tabular}{|c|c|c|c|c|c|}
\hline \multirow{2}{*}{$\begin{array}{l}\text { Sr. } \\
\text { No. }\end{array}$} & \multirow[t]{2}{*}{ Treatment } & \multirow{2}{*}{$\begin{array}{l}\text { Percentage } \\
\text { Nitrogen } \\
\text { content in } \\
\text { leaves }\end{array}$} & \multicolumn{3}{|c|}{ No. of jassids/3 leaves/ plant } \\
\hline & & & 2016 & 2017 & Pooled \\
\hline 1. & $\mathrm{~T}_{1}: 100 \%$ Nitrogen through Urea & $2.14(8.41 *)$ & $\begin{array}{l}6.43 \\
\left(2.62^{* *}\right)\end{array}$ & $7.45(2.82)$ & $6.94(2.72)$ \\
\hline 2. & $\mathrm{~T}_{2}: 100 \%$ Nitrogen through FYM & $1.83(7.77)$ & $2.50(1.73)$ & $2.97(1.85)$ & $2.74(1.80)$ \\
\hline 3. & $\mathrm{~T}_{3}: 100 \%$ Nitrogen though Vermicompost & $1.95(8.03)$ & $1.90(1.55)$ & $2.64(1.67)$ & $2.27(1.63)$ \\
\hline 4. & $\begin{array}{l}\mathrm{T}_{4}: 75 \% \text { Nitrogen through Urea }+25 \% \\
\text { Nitrogen through FYM }\end{array}$ & $2.18(8.49)$ & $5.92(2.47)$ & $6.37(2.60$ & $6.14(2.57)$ \\
\hline 5. & $\begin{array}{l}\mathrm{T}_{5}: 75 \% \text { Nitrogen through Urea }+25 \% \\
\text { Nitrogen though Vermicompost }\end{array}$ & $2.22(8.57)$ & $5.30(2.41)$ & $6.10(2.55)$ & $5.70(2.49)$ \\
\hline 6. & $\begin{array}{l}\mathrm{T}_{6}: 50 \% \text { Nitrogen through Urea }+50 \% \\
\text { Nitrogen though FYM }\end{array}$ & $1.98(8.09)$ & $5.01(2.34)$ & $5.72(2.48)$ & $5.36(2.41)$ \\
\hline 7. & $\begin{array}{l}\mathrm{T}_{7}: 50 \% \text { Nitrogen through Urea }+50 \% \\
\text { Nitrogen though Vermicompost }\end{array}$ & $2.12(8.37)$ & $2.98(1.85)$ & $3.73(2.04)$ & $3.36(1.95)$ \\
\hline 8. & $\begin{array}{l}\mathrm{T}_{8}: 25 \% \text { Nitrogen through Urea }+75 \% \\
\text { Nitrogen though FYM }\end{array}$ & $2.03(8.19)$ & $3.97(2.11)$ & $4.76(2.26)$ & $4.37(2.20)$ \\
\hline 9. & $\begin{array}{l}\mathrm{T}_{9}: 25 \% \text { Nitrogen through Urea }+75 \% \\
\text { Nitrogen though Vermicompost }\end{array}$ & $2.07(8.27)$ & $2.23(1.65)$ & $2.86(1.77)$ & $2.54(1.72)$ \\
\hline \multicolumn{2}{|c|}{ S. Em \pm} & 0.08 & 0.17 & 0.26 & 0.15 \\
\hline \multicolumn{2}{|c|}{ C. D. at $5 \%$} & 0.23 & 0.51 & 0.77 & 0.44 \\
\hline \multicolumn{2}{|c|}{ CV\% } & 1.59 & 14.24 & 20.04 & 11.72 \\
\hline
\end{tabular}

*Angular transformation,** Square root transformation.

Figures in the parentheses are transformed values.

Where, FYM= Farm Yard Manure 
Table.2 Effect of different source of nitrogen on population of whitefly, Bemisia tabaci (Genn.) infesting okra

\begin{tabular}{|c|c|c|c|c|c|}
\hline \multirow[t]{2}{*}{ Sr. Ni } & \multirow[t]{2}{*}{ Treatment } & \multirow{2}{*}{$\begin{array}{l}\text { Percentage Nitrog } \\
\text { content in leaves }\end{array}$} & \multicolumn{3}{|c|}{ No. of whitefly/3 leaves/plant } \\
\hline & & & 2016 & 2017 & Pooled \\
\hline 1. & $T_{1}: 100 \%$ Nitrogen through Urea & $2.14(8.41 *)$ & $7.66\left(2.85^{* *}\right)$ & $9.09(3.08)$ & $8.37(2.97$ \\
\hline 2. & $\mathrm{~T}_{2}: 100 \%$ Nitrogen through FYM & $1.83(7.77)$ & $1.94(1.52)$ & $3.31(1.91)$ & $2.62(1.74$ \\
\hline 3. & $\mathrm{~T}_{3}: 100 \%$ Nitrogen though Vermicompost & $1.95(8.03)$ & $1.50(1.41)$ & $3.19(1.82$ & $2.34(1.66$ \\
\hline 4. & $\begin{array}{l}\mathrm{T}_{4}: 75 \% \text { Nitrogen through Urea }+25 \% \text { Nitrogen through } \\
\text { FYM }\end{array}$ & $2.18(8.49)$ & $5.85(2.45)$ & $7.09(2.69$ & $6.47(2.64$ \\
\hline 5. & $\begin{array}{l}T_{5}: 75 \% \text { Nitrogen through Urea }+25 \% \text { Nitrogen though } \\
\text { Vermicompost }\end{array}$ & $2.22(8.57)$ & $5.19(2.38)$ & $6.53(2.63$ & $5.86(2.51$ \\
\hline 6. & $\begin{array}{l}\mathrm{T}_{6}: 50 \% \text { Nitrogen through Urea }+50 \% \text { Nitrogen though } \\
\text { FYM }\end{array}$ & $1.98(8.09)$ & $4.88(2.31)$ & $6.07(2.56$ & $5.47(2.44$ \\
\hline 7. & $\begin{array}{l}\mathrm{T}_{7}: 50 \% \text { Nitrogen through Urea }+50 \% \text { Nitrogen though } \\
\text { Vermicompost }\end{array}$ & $2.12(8.37)$ & $2.82(1.82)$ & $4.10(2.14)$ & $3.46(1.99$ \\
\hline 8. & $\begin{array}{l}\mathrm{T}_{8}: 25 \% \text { Nitrogen through Urea }+75 \% \text { Nitrogen though } \\
\text { FYM }\end{array}$ & $2.03(8.19)$ & $3.84(2.08)$ & $5.14(2.36$ & $4.49(2.23$ \\
\hline 9. & $\begin{array}{l}T_{9}: 25 \% \text { Nitrogen through Urea }+75 \% \text { Nitrogen though } \\
\text { Vermicompost }\end{array}$ & $2.07(8.27)$ & $2.13(1.62)$ & $3.47(1.99$ & $2.80(1.82$ \\
\hline \multicolumn{2}{|c|}{ S. Em \pm} & 0.08 & 0.17 & 0.25 & 0.14 \\
\hline \multicolumn{2}{|c|}{ C. D. at $5 \%$} & 0.23 & 0.51 & 0.76 & 0.43 \\
\hline \multicolumn{2}{|c|}{$\mathrm{CV} \%$} & 1.59 & 14.33 & 18.75 & 11.25 \\
\hline
\end{tabular}

*Angular transformation,** Square root transformation.

Figures in the parentheses are transformed values.

Where, FYM= Farm Yard Manure

Table.3 Effect of different source of nitrogen on fruit infestation (on number basis) due to shoot and fruit borer, Earias vittella (Fabricius) infesting okra

\begin{tabular}{|c|c|c|c|c|c|}
\hline \multirow[t]{2}{*}{ Sr. Ne } & \multirow[t]{2}{*}{ Treatment } & \multirow{2}{*}{$\begin{array}{l}\text { Percentage } \\
\text { Nitrogen } \\
\text { content in } \\
\text { leaves }\end{array}$} & \multicolumn{3}{|c|}{ Percent fruit infestation } \\
\hline & & & 2016 & 2017 & Pooled \\
\hline 1. & $\mathrm{~T}_{1}: 100 \%$ Nitrogen through Urea & $2.14(8.41 *)$ & $14.85(22.66$ & $13.93(21.91$ & $14.39(22.29)$ \\
\hline 2. & $\mathrm{~T}_{2}: 100 \%$ Nitrogen through FYM & $1.83(7.77)$ & $5.01(12.87)$ & $4.65(12.43)$ & $4.83(12.68)$ \\
\hline 3. & $\mathrm{~T}_{3}: 100 \%$ Nitrogen though Vermicompost & $1.95(8.03)$ & $3.13(10.18)$ & $3.23(10.28)$ & $3.18(10.23)$ \\
\hline 4. & $\begin{array}{l}\mathrm{T}_{4}: 75 \% \text { Nitrogen through Urea }+25 \% \text { Nitrogen through } \\
\text { FYM }\end{array}$ & $2.18(8.49)$ & $14.03(21.82$ & $11.89(20.16$ & $12.96(21.03)$ \\
\hline 5. & $\begin{array}{l}\mathrm{T}_{5}: 75 \% \text { Nitrogen through Urea }+25 \% \text { Nitrogen though } \\
\text { Vermicompost }\end{array}$ & $2.22(8.57)$ & $9.33(17.77)$ & $9.71(18.15)$ & $9.52(17.96)$ \\
\hline 6. & $\begin{array}{l}\mathrm{T}_{6}: 50 \% \text { Nitrogen through Urea }+50 \% \text { Nitrogen though } \\
\text { FYM }\end{array}$ & $1.98(8.09)$ & $9.42(17.70)$ & $8.97(17.39)$ & $9.20(17.56)$ \\
\hline 7. & $\begin{array}{l}\mathrm{T}_{7}: 50 \% \text { Nitrogen through Urea }+50 \% \text { Nitrogen though } \\
\text { Vermicompost }\end{array}$ & $2.12(8.37)$ & $5.48(13.53)$ & $5.98(14.15)$ & $5.73(13.85)$ \\
\hline 8. & $\begin{array}{l}\mathrm{T}_{8}: 25 \% \text { Nitrogen through Urea }+75 \% \text { Nitrogen though } \\
\text { FYM }\end{array}$ & $2.03(8.19)$ & $4.12(11.69)$ & $4.95(12.85)$ & $4.54(12.29)$ \\
\hline 9. & $\begin{array}{l}\mathrm{T}_{9}: 25 \% \text { Nitrogen through Urea }+75 \% \text { Nitrogen though } \\
\text { Vermicompost }\end{array}$ & $2.07(8.27)$ & $3.67(11.00)$ & $3.75(11.16)$ & $3.71(11.09)$ \\
\hline \multicolumn{2}{|r|}{ S. $\mathrm{Em} \pm$} & 0.08 & 1.05 & 0.45 & 0.66 \\
\hline \multicolumn{2}{|c|}{ C. D. at $5 \%$} & 0.23 & 3.14 & 1.35 & 1.98 \\
\hline \multicolumn{2}{|l|}{ CV\% } & 1.59 & 11.71 & 5.07 & 7.42 \\
\hline
\end{tabular}

* Angular transformation.

Figures in the parentheses are transformed values.

Where, FYM= Farm Yard Manure 
Table.4 Effect of different source of nitrogen on fruit infestation (on weight basis) due to shoot and fruit borer, Earias vittella (Fabricius) infesting okra

\begin{tabular}{|c|c|c|c|c|c|}
\hline \multirow{2}{*}{$\begin{array}{l}\text { Sr. } \\
\text { No. }\end{array}$} & \multirow[t]{2}{*}{ Treatment } & \multicolumn{4}{|c|}{ Percentag Percent fruit infestation } \\
\hline & & $\begin{array}{l}\text { Nitrogen } \\
\text { content in } \\
\text { leaves }\end{array}$ & 2016 & 2017 & Pooled \\
\hline 1. & $\mathrm{~T}_{1}: 100 \%$ Nitrogen through Urea & $\begin{array}{l}2.14 \\
(8.41 *)\end{array}$ & $\begin{array}{l}20.23 \\
(26.71 *)\end{array}$ & $\begin{array}{l}22.87 \\
(28.53)\end{array}$ & $21.55(27.66)$ \\
\hline 2. & $\mathrm{~T}_{2}: 100 \%$ Nitrogen through FYM & $1.83(7.77$ & $7.83(16.23$ & $\begin{array}{l}10.50 \\
(18.82)\end{array}$ & $9.17(17.58)$ \\
\hline 3. & $\mathrm{~T}_{3}: 100 \%$ Nitrogen though Vermicompost & $1.95(8.03$ & $7.30(15.67$ & $9.99(18.3$ & $8.65(17.08)$ \\
\hline 4. & $\begin{array}{l}\mathrm{T}_{4}: 75 \% \text { Nitrogen through Urea }+25 \% \text { Nitrogen } \\
\text { through FYM }\end{array}$ & $2.18(8.49$ & $\begin{array}{l}12.28 \\
(20.46)\end{array}$ & $\frac{14.93}{(22.62)}$ & $13.61(21.57)$ \\
\hline 5. & $\begin{array}{l}\mathrm{T}_{5}: 75 \% \text { Nitrogen through Urea }+25 \% \text { Nitrogen } \\
\text { though Vermicompost }\end{array}$ & $2.22(8.57$ & $\begin{array}{l}13.64 \\
(21.64)\end{array}$ & $\begin{array}{l}16.32 \\
(23.81)\end{array}$ & $14.98(22.76)$ \\
\hline 6. & $\begin{array}{l}\mathrm{T}_{6}: 50 \% \text { Nitrogen through Urea }+50 \% \text { Nitrogen } \\
\text { though FYM }\end{array}$ & $1.98(8.09$ & $\begin{array}{l}10.96 \\
(19.27)\end{array}$ & $\begin{array}{l}13.64 \\
(21.66)\end{array}$ & $12.30(20.50)$ \\
\hline 7. & $\begin{array}{l}\mathrm{T}_{7}: 50 \% \text { Nitrogen through Urea }+50 \% \text { Nitrogen } \\
\text { though Vermicompost }\end{array}$ & $2.12(8.37$ & $9.63(18.06$ & $\begin{array}{l}12.31 \\
(20.47)\end{array}$ & $10.97(19.31)$ \\
\hline 8. & $\begin{array}{l}\mathrm{T}_{8}: 25 \% \text { Nitrogen through Urea }+75 \% \text { Nitrogen } \\
\text { though FYM }\end{array}$ & $2.03(8.19$ & $9.31(17.61$ & $\begin{array}{l}11.89 \\
(20.06)\end{array}$ & $10.60(18.87)$ \\
\hline 9. & $\begin{array}{l}\mathrm{T}_{9}: 25 \% \text { Nitrogen through Urea }+75 \% \text { Nitrogen } \\
\text { though Vermicompost }\end{array}$ & $2.07(8.27$ & $8.98(17.31$ & $\begin{array}{l}11.66 \\
(19.82)\end{array}$ & $10.32(18.70)$ \\
\hline \multicolumn{2}{|r|}{ S. $\mathrm{Em} \pm$} & 0.08 & 1.12 & 0.91 & 0.82 \\
\hline \multicolumn{2}{|c|}{ C. D. at $5 \%$} & 0.23 & 3.37 & 2.73 & 2.45 \\
\hline \multicolumn{2}{|c|}{$\mathrm{CV} \%$} & 1.59 & 10.13 & 7.32 & 6.92 \\
\hline
\end{tabular}

* Angular transformation.

Figures in the parentheses are transformed values.

Where, FYM= Farm Yard Manure

Fig.1 Effect of different source of nitrogen on population of Jassid and whitefly, infesting okra (Pooled, kharif 2016 \& 2017)

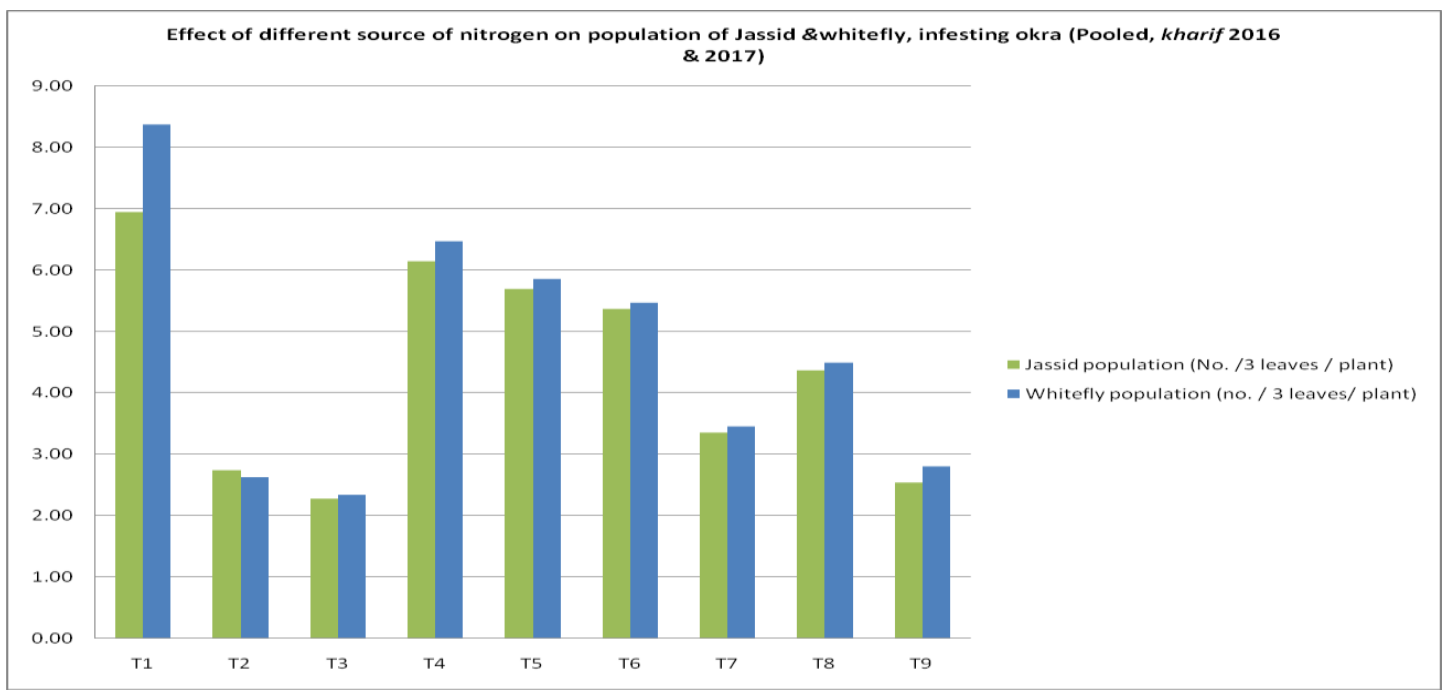


Fig.2 Effect of different source of nitrogen on percent shoot infestation of Shoot borer (Earias vittella), infesting okra (Pooled, kharif 2016 \& 2017)

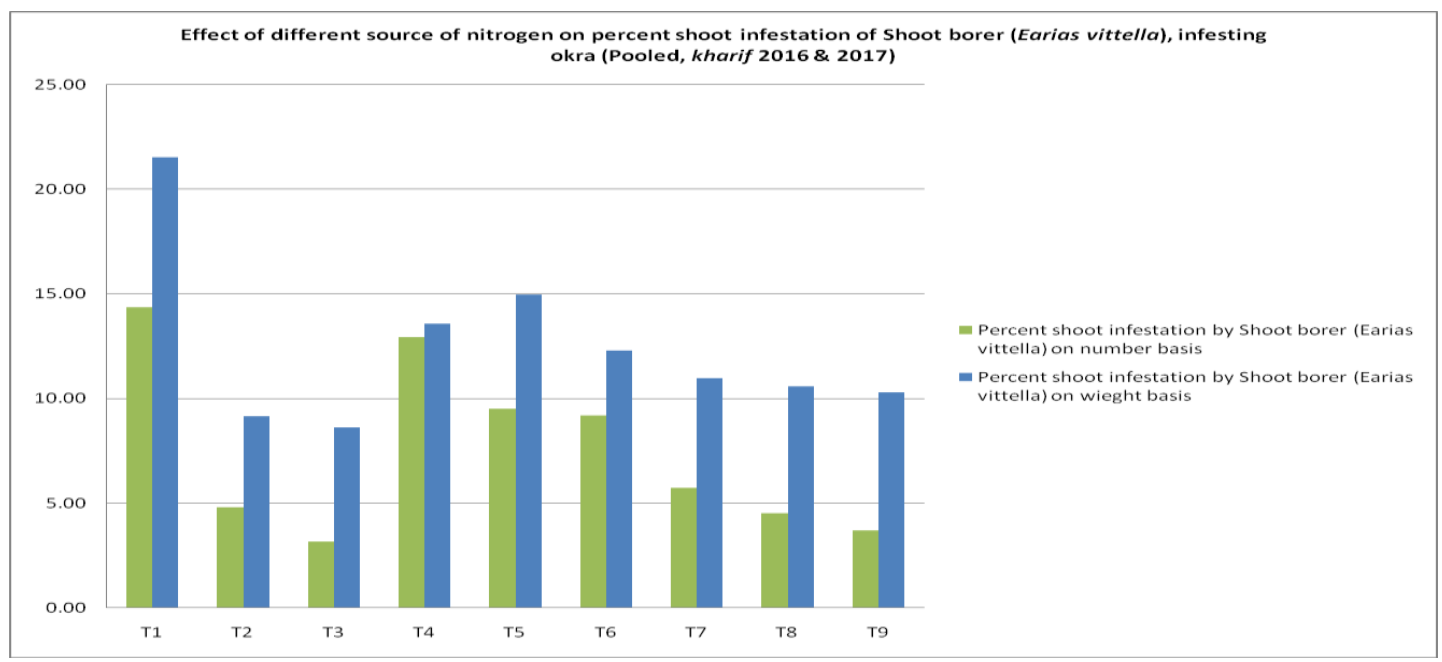

The finding of Prakash et al., (2002), Prakash and Bhadoria (2004), Tripathy (2004), Yadav (2004) and Rakshit (2009) confirms the result of present investigation, where similar results were obtained. Prakash et al., (2002) reported lower percentage of fruit borer infestation in okra treated with farm yard manure (FYM) and vermicompost. Prakash and Bhadoria (2004) evaluated the relative efficacy of organic manures in improving pest tolerance of okra. Among the organic manures tested, FYM showed the tolerance to attack by $E$. vittella. Tripathy et al., (2004) found that the integrated application of 75 per cent recommended dose of fertilizer combined with vermicompost @ 5 t/ha gave significantly higher marketable fruit yield $(91.75 \mathrm{q} / \mathrm{ha})$ followed by 50 per cent recommended dose of fertilizer combined with vermicompost @ 5 t/ha (88.31 q/ha), 75 and 50 per cent recommended dose of fertilizer combined with neem cake @ 2.5 t/ha (86.03 q/ha and $78.5 \mathrm{q} / \mathrm{ha}$, respectively). Yadav et al., (2004) studied the effects of different levels of organic manures on yield of okra. The treatment with 50 per cent recommended dose of nitrogen as urea combined with 50 per cent recommended dose of nitrogen as poultry manure recorded the highest yield. Rakshit (2009) observed that the application of chemical fertilizers resulted in significantly higher per cent of infested plants due to E. vittella in okra as compared to all treatments with organic nutrient sources. Suppression of shoot and fruit borer was significantly lower in FYM.

\section{Acknowledgement}

The authors are sincerely thankful to the Department of Entomology, Rajasthan Agricultural Research Institute, Durgapura, Jaipur for making available the facilities to conduct the research programme.

\section{References}

Anonymous 2016. Biology of Okra, Abelmoschus esculentus L. (Moench), Series of crop specific biology documents. $\mathrm{Pp} 2$.

Anonymous 2016-17. Horticultural statistics at a glance 2017. All India area, production and productivity of okra, onion and pea, pp 150.

Jackson, M.L. 1973. Soil chemical analysis. Prentice Hall of India Pvt. Ltd., New Delhi. 
Pareek, B.L. and Bhargava, M.C., 2003. Estimation of avoidable losses in vegetable crops caused by borers under semi-arid conditions of Rajasthan. Insect Environment, 9 (1): 59-60.

Prakash, Y. S. and Bhadoria, P. B. S. 2004. Relative efficacy of different organic manures on the performance of okra (Abelmoschus esculentus L.) grown in Lateritic soil. Tropical Agriculture, 81(4): 197-203.

Prakash, Y. S., Bhadoria, P. B. S. and Amitava, R. 2002, Relative efficiency of organic manures in improving resistance and pest tolerance of okra. Ann. Agri. Res., 23(1): 525-531.

Rakshit, A. 2009. Performance of Abelmoschus esculentus L. Cv. Arka Anamika (IIHR Sel 10) grown in New Alluvail region of West Bengal, India with different locally available organic manures. $e$ - Journal of Science \& Technology, 3(1): 31-43.
Srinivasa, R. and Rajendran, R., 2003. Joint action potential of neem with other plant extracts against the leaf hopper Amrasca devastance (Distant) on Okra. Pest Mangt. Econ. Zool., 10 (1): 131-136.

Surekha, J. and Rao, P. A. 2001. Management of aphids on bhindi with organic sources of $\mathrm{N} \quad \mathrm{K}$ and certain insecticides. Andhra Agric. J., 48 (1): 56-60.

Tripathy, P., Bhattacharyay, B. and Maity, T. K. 2004. Response of okra (Abelmoschus esculentus L. Moench) to integrated nutrient management system. Orissa Journal of Horticulture, 32(2): 14-18.

Yadav, P., Singh, P., Yadav, R. L. and Ram, L. 2004. Ameliorative potential of organic manures and nitrogen levels on okra Cv. Varsha Uphar. Haryana Journal of Horticultural Sciences, 33(1/2): 124-126.

\section{How to cite this article:}

Jat, S.M., A.S. Baloda, Purushotam Sharma and Sharwan Lal Jat. 2019. Evaluation of Effect of Different Nitrogen Sources on Major Insect Pests Infesting Okra, Abelmoschus esculentus (L.) Moench. under Semi Arid Region of Rajasthan, India. Int.J.Curr.Microbiol.App.Sci. 8(02): 2985-2992. doi: https://doi.org/10.20546/ijcmas.2019.802.348 